\title{
Cracking the Cocoon: Promoting Self-Directed Lifelong Learning in EFL Pre-service Teachers in Chile Through the Guided Use of Social Media Tools
}

\author{
Charbonneau-Gowdy, Paula ${ }^{\text {; }}$, Salinas, Danisa ${ }^{\text {a }}$
}

${ }^{\mathrm{a}}$ Faculty of Education, Universidad Andres Bello, Chile

\begin{abstract}
While is it an obvious observation that in the $21^{\text {st }}$ century individuals will need to continue to learn to keep pace with the rapid changes that affect their personal and professional lives, the practicalities of doing so are daunting. Where do we begin to instill a sense of self-directed learning that leads to a lifelong pursuit of knowledge and, more importantly, how? The aim of our study was to determine the influence of providing guided support in the use of social media to a group of future English as a Foreign Language, (EFL) teachers in Chile. In this context, traditional teaching practices and cultural norms, not to mention resistance to technology adoption often stand in the way of learner agency and evolving self-directed learner identities. We focussed on pre-service teachers as a strategic step in changing these trajectories. Our results provide powerful evidence of change in this group of emerging teachers not only in increased responsibility for learning but in a metacognitive awareness of 'how' to learn - key ingredients in reaching personal and professional potential. We conclude that technology needs to be re-conceptualized as not only an information provider but as a key player in constructing self-directed, lifelong learners.
\end{abstract}

Keywords: self-directed learning, social media, lifelong learning, Teacher Education, ICT, learner identities 


\section{Introduction}

"When education fails to keep pace with technology, the result is inequality."

(The Economist, 2017)

In a recent special report on lifelong learning, the influential periodical, The Economist, painted a dire picture of the prospects of doing nothing about the current speed of change that is affecting most of our lives in terms of automation and knowledge development. Their foresight strongly suggests that citizens everywhere in our increasingly global community will face the disappearance at an alarming rate of traditional jobs and their own lack of skills to fit into newly evolving ones that are accompanying advances in new technologies. Lifelong, self-directed learning will become more crucial than ever before in the history of mankind, they argue. At the same time, they call for opportunities for lifelong learning that are radically different than current ones, especially if we wish to avoid perpetuating, or indeed worsening, the inequalities already existing.

Keeping pace with the changes that are surrounding us as citizens has historically been a challenge for education. Like an ocean liner, the direction of educational systems is painstakingly slow to turn. Indeed in many parts of the world, a majority of educational institutions seem to be still preparing individuals for 20th century working roles. In Chile where we work in education, such is certainly the case. Yet, as educators whose task it is to prepare students to flourish in a global community and to enjoy access to equal opportunities for reaching their potential of productivity and happiness, is it not within our responsibility in classrooms to guide them towards actions that will achieve those ends? As the writers of The Economist (2017) strongly point out: "Lifelong learning starts at school". Those writers also add that learning to think, to develop metacognition (p. 9) and to exploit new technologies are also part of this process and reflect the "true" aim of any effective educational system - to promote change.

The study we report on in this paper sought to pursue such an aim. In the context of Chile where rote learning, passive and disengaged learners, assessment-driven teaching reflecting information transfer pedagogies, as well as where inequitable access to quality education are all culturally and deeply embedded in the educational system, the need for change has become a national outcry. Our purpose was to add to initiatives in the country that are attempting to dismantle this national educational dilemma through strategically working with future teachers. Strong evidence in our own EFL field of study of the dynamic nature of identities (Norton \& Toohey, 2011), i.e. changing and evolving depending on the contextual conditions, was further impetus. The questions that preoccupied us in this particular case were: 
1. What influence, if any, does guided support of social networking media have on the learner identities of a group of Chilean EFL pre-service teachers?

2. How does the guided use of these technologies influence, if at all, their investment in self-directed or lifelong learning?

\section{Literature Review}

Some have argued that 'ideal' self-directed learners accept full control over their learning process and that self-directedness is an autonomous enterprise. Yet these views clearly defy postmodern perspectives of learning. Vygotsky's (1978) foundational social cultural theory places learning squarely in the realm of a social-interactive activity and the precursor to cognition, i.e. learning. From this perspective then if learning is inherently collaborative, self-directed learners must be considered neither dependent nor independent but rather interdependent learners (Garrison, 1992). In other words, the identity of self-directed learners is tied closely to the social worlds they inhabit including the cultures of formal learning spaces.

The notion of identity and its implication in self-directed learning is particularly relevant to our study. Gee (2000) defines identity simply as the way one is in a particular context. Importantly, a way of being is dynamic based on whether the context and practices are limiting and constraining or alternatively offer enhanced opportunities for social interaction and human agency (Norton, 2011, p.417). By agency is referenced "people's ability to make choices, to take control, self-regulate, and thereby pursue their goals as individuals leading potentially to personal or social transformation" (Duff, 2012, p. 417). Imbedded in the importance Norton places on contexts of learning, regardless of the discipline, is the potential for teaching practices to be transformative by offering learners more powerful positions than they may otherwise occupy in other social cultural contexts. A further implication is that the uptake of these powerful positions situates learners precisely within enriched conditions for investing as self-directed, lifelong learners.

Norton and many others within Second Language (SL) education (Lin et al., 2016; Thorne et al., 2015) have examined conditions for promoting empowered identities in learners through teaching practices. Increasingly, social media and networking technologies are considered to play a major role in these settings. As Thorne et al. (2015) argue: "Internetmediated interaction, both within and outside of educational settings, has the potential to provide...learners with a range of possibilities for engaged self-representation and the construction of identities." (p. 229). While these researchers have shown the potential of technology to be identity enhancing, many caution that teachers play an important role in the potential value of technology to promote such positive changes. Thus, depending on their choice and use of technologies, teachers can provide or deny learners with opportunities to enhance their identities within the learning context. Technologies that offer 
such opportunities have been shown to be those that support community building (Freiermuth \& Huang, 2012; that reduce social barriers and that promote engagement (Klimanova \& Dembovskaya, 2013). In other words, social-networking technology potentially provides the ideal conditions for building learner identities that are self-directed.

Discussions around the power of technology to change more than the way we do but also the way we are, are only beginning (Darvin \& Norton, 2015). Connections that need to be drawn and pursued between enriched social cultural contexts, social networking technologies and opportunities for identity construction leading to self-directed learners have been relatively unexplored.

\section{Methodology}

Our study took place in two phases between September 2015 and December 2016. We chose to conduct the inquiry within the qualitative paradigm, using an Action Research methodology as a framework and classroom-based-research methods. The ethnographic tools available to us within a qualitative research paradigm served to help us unravel the complexities that typically exist in any learning context, most notably classrooms, including the one we studied. The increasing recognition of classroom-based research leading to change, where it matters, was a further driver in our decision to conduct the inquiry.

\subsection{Context}

Chile suffers from a deep and complex array of issues in terms of its education system. Economically, it is the most stable country in South America and is a proud member of the OECD. The latter factor has helped in defining some of the areas of the system most in need of attention. Teacher education is one of these areas. The general profile of teachers in the current school system is characterized as lacking in three important areas: firstly, acceptable English language levels; secondly, knowledge and training in the use of effective $21^{\text {st }}$ century pedagogies including the use of technology for learning and thirdly, openness to change through top-down professional development. Since 2012, Ministry of Education efforts have attempted to address these issues by upgrading teacher education programs. At the heart of these initiatives is to provide quality teaching across the education system, and dismantle deep-seeded inequities within the society.

\subsection{Participants}

Twenty-one pre-service teachers in their first year of a four-year English Pedagogical Program took part in the study. Many are first generational attending higher education institutions. Along with the weight of financial pressure, many learners come into the higher education setting burdened by a cocoon-like upbringing that are considered tied to 
highly protective, in some cases over-protective family practices dictated by cultural norms, an isolated society geographically and exposure to years of pedagogical coddling by perhaps well-intentioned teachers. As a result, many seem to lack the ability to accept responsibility for their learning, nor the know-how to learn effectively and efficiently - not indicative of strong future leaders of educational reforms, let alone lifelong learners.

\subsection{Research Design and Analysis}

In the initial 4-month phase of the study, the Teacher Educator (TE), and co-author in the study, met with the participants and proposed a 'skills challenge' to help address each of their individual learning difficulties based on skill testing results. Participants agreed to take part in daily practice of their 'weaker' language skill by making use of authentic materials available through the use of social media technology. They also agreed to keep an online $\log$ of their efforts in a class blog, Blogspot, and to meet regularly with the TE to discuss progress and individual challenges adhering to their Plan.

The data collection process in the first phase of the study involved using the following ethnographic tools: 1) observations from classroom interactions; 2) recorded individual and focus group interviews; 3 ) document analysis of the various assignments generated by the participants; 4) field notes, for example test scores plus informal conversations with the participants and other faculty. In the second phase of the study, in the fourth semester, data was collected from end-of-year individual reflections written by each of the participants. Reflective notes were also recorded over the period of the study by the teacher/researcher. Signed consent was sought from each of the participants in order to use the data collected for academic purposes. For privacy purposes, pseudonyms replaced names of the participants.

The significant data that was generated from the various data sets were analyzed on an ongoing basis during the first phase of the study using standard qualitative methods for uncovering salient themes and patterns. In the second phase, these salient themes were then cross-referenced with data generated from the analysis of the follow-up participant reflections. We acknowledge that the analysis presented here is the not sole interpretation of the data that can be applied. Also, given the space limitations, we have chosen only representative excerpts from various data sets to support our analysis and conclusions. 


\section{Analysis and Finding}

From the analysis of the multiple data sets, two major themes that emerged suggested that technology supported changes in identities existed on two levels: 1) at the TE level and 2) at the Pre-service Student level. A deeper analysis of these themes revealed that by changing her teaching practices and her role as teacher from passive conveyer of information to supporter and guide, the TE was able to provide the ideal conditions for learners in her class to invest in taking on more agentive roles in their learning that lead to evidence of emerging self-directedness. At both levels, social networking technology was critical to these changes. In the following sections we explain the major findings on each level.

\subsection{Technology Support for Self-directedness at the Teacher Educator Level}

The TE reported that key to the success she had with the project was a) the encouragement and support from a more knowledgeable tech savvy colleague and b) the affordances of the technology platform used by students for recording their progress in the "Skills Challenge". In online discussions, participants shared their challenges and ongoing success with classmates and their TE in Blogspot. The community building opportunities offered by this social networking technology were considered by the TE to be at the root of the changes that took place during the project. The TE explains the powerful role that technology played in helping to build the kinds of solid learning communities necessary for supporting selfdirected identities for herself and among her students in the following extract: "From this 'project' learning experience, all my classes have had a different approach: use of technological resources. It is hard, initially, to move away from the comfort zone, but once one makes use of it and sees the benefits, it is impossible to move back." We understand from these words that the TE is recognizing that the advantages of technology, although they imply a move away from the way things are and the way one is, i.e. as information provider and a transfer scenario, that the rewards are impressive, both personally as a professional and for her students. In other words, her identity as a TE has evolved in unison with her students' identities. Indeed, the TE sees "it is impossible to move back", suggesting strongly a continued investment in teaching practices supported by social media and networking technologies. 


\subsection{Technology Support for Self-directedness at the Pre-service Student Teacher Level}

Turning toward the second theme that emerged in the analysis and that helped explain changes in the self-directedness of the student teachers, we draw a picture of what transpired during Phase 1 and also a year later in Phase 2, from their perspective. The data sets revealed that many of the participants witnessed a deep change in the way they viewed themselves as learners. From their testimonies, it was clear that the Skills Challenge that the TE initiated led to a new sense of being self-directed and responsible. Many expressed witnessing a movement away from being dependent toward interdependent learning. For these individuals, the change began with a sense of awareness of their strengths and weaknesses, an awareness fostered by support and encouragement from their community of teacher and classmates in the online blog. Indeed, the TE and students both attested to the Blogspot providing a unique forum for interacting and connecting between class time that was previously unavailable. Many claimed with deep conviction that this online encouragement was crucial for their sustained efforts to work on their difficulties. Another awareness that apparently influenced their continued investment in change was a sense of improvement. Several spoke of the pride they felt and the determination to continue being self-directed as their abilities in their particular difficult skill improved. Engaging online was reportedly essential to these emerging changes in awareness, determination, perseverance and feelings of community support that had been heretofore not part of their learning process. The social networking site became the interface for these influences to play a role in the oftentimes-difficult changes towards self-directedness that occurred during the inquiry. In Table 1, we provide representative excerpts from the data to support this analysis. 
Table 1: Technology Influence on Self-directed Identities: Excerpts form the data

\begin{tabular}{|l|l|}
\hline Awareness & $\begin{array}{l}\text { "What I liked of this course is teacher gave us the possibility to write articles at } \\
\text { home and upload them in the Blog, because I can't write under pressure, I can't } \\
\text { think, and I can't write correctly. Now I feel very good about myself and I hope } \\
\text { to continue improving my English." }\end{array}$ \\
\hline Determination & $\begin{array}{l}\text { "I have a more personalized education [working in the Blogpspot] and I try to } \\
\text { improve every day." }\end{array}$ \\
\hline Perseverance & $\begin{array}{l}\text { My pronunciation and writing need be improved even more. I have many } \\
\text { grammatical errors when speaking and writing, but I know that I can improve } \\
\text { that doing the extra activities using my computer at home." }\end{array}$ \\
\hline within \\
Community & $\begin{array}{l}\text { "I have improved in my weaknesses thank to my teachers and my classmates" } \\
\text { "Miss xxx was very happy and enthusiastic about the progress I had made. That } \\
\text { of course encouraged me to continue giving my best." } \\
\text { "I have a more personalized education and I try to improve every day" }\end{array}$ \\
\hline
\end{tabular}

A follow up data collection a year after the initial inquiry with this group of participants provides insight into the sustainability of these findings. Analysis of these data sets indicated that identity changes resulting in the online Skills Challenge initiative prevailed for many of the participants. The outward signs of a majority of these learners characterized by a growing sense of self-directedness, awareness, determination, perseverance and interdependence within community were uncovered. One of the pre-service teachers witnesses these influences in her comment on the December 2016 reflection: "I never thought that we would be here, but I am. This is what I like and what I really want to do. So, I have to do everything that I can to reach my goal." Her use of "we" is significant in that it reveals the importance she places on her interconnectedness with others in her journey to succeed in her goal to become a competent speaker of English and teacher. In her words, we see the awareness of her path and the inner strength that she has to continue to learn and improve. Her determination in preparing for her role as a future teacher is clear and her realization of what it takes, in her words "everything I can" is obvious. Indeed, the sentiments expressed in these words represent we believe, a growing sense of responsibility and self-directedness, typically unusual among Chilean students. Similar sentiments also surfaced in many of her classmates during the longitudinal study as well. These findings speak to the powerful sustained change that was initiated through the Skills-Challenge supported by social networking technology. 


\section{Conclusion}

As the warning cry rises for educational institutions to accept their role in preparing selfdirected and life-long learners, traditional countries like Chile have further to go and more to lose through inaction. Part of what stands in the way is a clear course of action. The results of our inquiry we believe can to add to practical responses needed to begin to respond to that question. Our findings confirm that integrating social media and networking technologies into a teacher education program can offer hope, at least for this particular group of novice teachers, through guided opportunities for them to construct the kinds of self-directed identities that lead to life-long learning. The effective use of social networking technologies as an interface for strong interdependency among a TE and future teachers was critical in terms of the positive results. We feel strongly that these results offer a model for teacher educators, indeed all stakeholders in education for exploring and documenting the use of such technologies for guiding self-directed learning in their own contexts.

\section{References.}

Creese, A. \& Blackledge, A. (2015). Translanguaging and identity in educational settings. Annual Review of Applied Linguistics, 35, pp. 20-35.

Darvin, R. and Norton, B., 2015. Identity and the power of investment in applied linguistics. Annual Review of Applied Linguistics, 35, pp. 36-56.

Duff, P. (2012). Identity, agency, and SLA. In A. Mackey and S. Gass (Eds),

Handbook of Second Language Acquisition, (pp. 410-426) London: Routhledge.

Freiermuth, M. R., \& Huang, H. C. (2012). Bringing Japan and Taiwan closer electronically: A

look at an intercultural online synchronic chat task and its effect on motivation.

Language Teaching Research, 16(1), 61-88.

Garrison, D. (1992). Critical thinking and self-directed learning in adult education: An

analysis of responsibility and control issues. Adult Education Quarterly, 42(3), pp. 136148.

Klimanova, L., \& Dembovskaya, S. (2013). L2 identity, discourse, and social networking in Russian. Language Learning \& Technology, 17(1), 69-88. Retrieved from http://llt.msu.edu/issues/february2013/klimanovadembovskaya.pdf

Lin, C.-H., Warschauer, M., \& Blake, R. (2016). Language learning through social networks:

Perceptions and reality. Language Learning \& Technology, 20(1), 124-147. Retrieved from http://llt.msu.edu/issues/february2016/linwarschauerblake.pdf

Norton, B., \& Toohey, K. (2011). Identity, language learning, and social change.

Language Teaching, 44(4), 412-446. 
Stowell, F. (2013) "The appreciative inquiry method-A suitable candidate for action research?”, Systems Research and Behavioral Science, 30, pp.15-30.

The Economist (2017, January 14). A special report on lifelong learning. p.9, Special Report Section, 1-16.

Thorne, S., Sauro, S. \& Smith, B. (2015). Technologies, identity and expressive activities. Annual Review of Applied Linguistics, 35 (2015), pp. 215-233.

Vygotsky, L. (1978). Mind in Society: The Development of Higher Psychological

Processes, In Cole, M., John-Steiner, V., Scribner, S. and Souberman, E. (Eds.), Cambridge, MA: Harvard University Press. 